\title{
The Armed resistance yrigoyenista post blow of 1930 A bibliographical analysis
}

\author{
Juan Alejandro Costa* \\ National University of General Sarmiento, Argentina
}

Submission: May 25, 2019; Published: June 14, 2019

*Corresponding author: Juan Alejandro Costa, University Professor of Higher Education in History, National University of General Sarmiento, Argentina

\section{Mini Review}

The first military dictatorship of Argentina opened debates around different analytical perspectives. Their motives, their causes, the actors, the political movements and their actions were fields dealt with extensively by Argentine historiography. However, the recent publication of the book entitled "Long live Yrigoyen! Long live the revolution! The radical armed struggle in the infamous decade. 1930-1933 " by Charo López Marsano and Ernesto Salas shows the little or no participation of the Radical resistance in the historiographical works. For this reason, the analysis of this book aims to highlight the particularities of its object of study and proposals. Therefore, this work is a simple but potentially rich exercise to highlight the significant contributions of this publication in the study of Argentine politics and society in the first years of the 1930s. In general, the book tries to address the situations of Radicals more aligned with the personalist faction, followers of Yrigoyen, who opted for armed action after the coup of Uriburu and the first years of Justo's government. It is interesting the approach to several insurrectional events that in the book are detailed with almost anecdotal details. Taking these facts and placing them in orbit gives us a much broader picture of the role assumed by the Radical Party in all its expressions. Undoubtedly, the contradictions about which strategies to take inside the party marked the twists and turns of the party reorganization. Both personalistas-yrigoyenistas and antipersonalistas had different strategies with respect to the functioning of the party in such an adverse conjuncture.

In this sense, it is valid to affirm that the option of armed resistance responds to a classic revolutionary strategy of the radicalism of the late nineteenth and early twentieth centuries. However, in a different scenario as was Argentina in 1930 the bulk of the Radical Party and those who maintained hierarchical positions in the National Committee of the party opted for an abstentionist policy, a strategy more linked to a party that transited its maturation in the heat of a "full" democracy as inaugurated by the election of 1916. Then, the book puts in evidence these questions. Therefore, in a first part, the repressive position of the de facto government of Uriburu to intimidate the Radicals will be questioned. In a second instance, it will be mentioned the main features that the authors propose to demonstrate the importance of the armed resistance of the yrigoyenistas within the Radical Party during the first years of the 30s. At first, both authors make a brief synopsis on the characteristics of the political actors that had the most resonance in society prior to the coup of 1930. In carrying it out, they intend to emphasize the fundamental factor that influenced the coup process: A new position that the popular classes had managed to conquer after the Sáenz Peña law was germinating within the conservative sectors a desire to reestablish the society prior to 1916 . After highlighting the reason for the coup of 30 , the authors are introduced to analyze the dictatorship.

For this, they carry out observations regarding the repressive policy of the regime. In the book, special coverage is given to figures of the military corps who were pioneers in the use of methods of torture towards political prisoners and enemies of the regime. Likewise, the importance assigned to Martial Law, decreed by Uriburu, is fundamental. In this sense, it forms part of the argumentative basis because it is the first formal regulation that allowed punishment and death penalty to any political enemy, including the Radicals, under the condemnation of a military tribunal. In another passage of the book the authors make characterizations and postulates about three political and military figures of relevance in the context. Alvear, Uriburu and Justo are focused on the political strategies and desires that they intended to impose in the first years of the dictatorship. These exposed points show to be a first part of the book, where we try to contextualize the first years of the de facto government of 1930, emphasizing the positions of partisan and ideological groups, the strategies of coercion and repression of the regime and the most important political figures of those times. In a second part of the book, the authors delve into the analysis of the insurrectional focuses of the Radical groups linked to Yrigoyen between 19301933 [1]. It is important for the authors to highlight the strategy of this faction in contrast to the one predominantly taken by the 
great majority of the radical party, the electoral abstention. In this sense, they begin by addressing different armed actions of these groups in an isolated manner.

The rebellion in Cordoba, the uprising of Severo Toranzo, the uprising of Gregorio Pomar and the revolution of the Kennedy brothers are some of the most prominent acts of armed insurrection of those first years of the dictatorship. Later on, they made a rather thorough analysis of the insurrectional cases of the country's coastline, where they argued they were carried out with a high degree of implication and organization. In this sense, they argue that in this region an organization was structured, more strategic and planned, which had strongly delimited an attempt of revolution whose objective would be to erode the dictatorial order, putting an end to its advance against the democratic and republican freedoms of the country. In short, this book seeks to highlight these armed actions of the personalist sector of Radicalism in order to position them in the historiographical window as important actors of the first years of the 1930s. At the same time, they intend to highlight the tension between this strategy and the abstentionist position that opted to take the bulk of the Radical Party, presenting us with a contradiction inside the party. Aspect very little considered by local historiography.

\section{References}

1. López Marsano, Charo, Salas, Ernesto (2017) Long live Yrigoyen! Long live the revolution! The Radical armed struggle in the infamous decade, 1930-1933. Editorial Biblos, Autonomous City of Bs. As, Argentina.

\section{Your next submission with Juniper Publishers will reach you the below assets}

- Quality Editorial service

- Swift Peer Review

- Reprints availability

- E-prints Service

- Manuscript Podcast for convenient understanding

- Global attainment for your research

- Manuscript accessibility in different formats

( Pdf, E-pub, Full Text, Audio)

- Unceasing customer service

Track the below URL for one-step submission https://juniperpublishers.com/online-submission.php 